\title{
Algae Biomass as a Potential Source of Liquid Fuels
}

\author{
Marcin Dębowski ${ }^{1, *(\mathbb{D})}$, Marcin Zieliński ${ }^{1}$ (D) Izabela Świca $^{1}$ and Joanna Kazimierowicz ${ }^{2} \mathbb{D}$ \\ 1 Department of Environment Engineering, Faculty of Geoengineering, University of Warmia and Mazury in \\ Olsztyn, 10-720 Olsztyn, Poland; marcin.zielinski@uwm.edu.pl (M.Z.); izabela.swica@uwm.edu.pl (I.Ś.) \\ 2 Department of Water Supply and Sewage Systems, Faculty of Civil Engineering and Environmental Sciences, \\ Bialystok University of Technology, 15-351 Bialystok, Poland; j.kazimierowicz@pb.edu.pl \\ * Correspondence: marcin.debowski@uwm.edu.pl
}

check for

updates

Citation: Dębowski, M.; Zieliński, M.; Świca, I.; Kazimierowicz, J. Algae Biomass as a Potential Source of Liquid Fuels. Phycology 2021, 1 , 105-118. https://doi.org/10.3390/ phycology1020008

Academic Editor: Leonel Pereira

Received: 2 October 2021

Accepted: 18 November 2021

Published: 19 November 2021

Publisher's Note: MDPI stays neutral with regard to jurisdictional claims in published maps and institutional affiliations.

Copyright: (c) 2021 by the authors. Licensee MDPI, Basel, Switzerland. This article is an open access article distributed under the terms and conditions of the Creative Commons Attribution (CC BY) license (https:// creativecommons.org/licenses/by/ $4.0 /)$.

\begin{abstract}
Algae biomass is perceived as a prospective source of many types of biofuels, including biogas and biomethane produced in the anaerobic digestion process, ethanol from alcoholic fermentation, biodiesel synthesized from lipid reserve substances, and biohydrogen generated in photobiological transformations. Environmental and economic analyses as well as technological considerations indicate that methane fermentation integrated with bio-oil recovery is one of the most justified directions of energy use of microalgae biomass for energy purposes. A promising direction in the development of bioenergy systems based on the use of microalgae is their integration with waste and pollution neutralization technologies. The use of wastewater, another liquid waste, or flue gases can reduce the costs of biofuel production while having a measurable environmental effect.
\end{abstract}

Keywords: algae; renewable energy source; biofuels; biogas; bio-oil; biohydrogen

\section{Introduction}

The development and large-scale implementation of clean, effective, and renewable technologies for energy production is today becoming a challenge for scientists and a priority to energy system operators. The immediate reason for this situation is the need to reduce greenhouse gas emissions, which entails reduced extraction and exploitation of conventional energy carriers, including coal, natural gas, and crude oil.

It is commonly believed that the goals presented above can be partially achieved by stimulating the development of unconventional energy systems based on the use of biomass of various characteristics and origins [1,2]. This common viewpoint has, however, been challenged in a few works. Fargione et al. (2008) and Searchinger et al. (2008) demonstrated that the irrational management of the resources typical of energy crops might, in fact, lead to a negative balance in the volume of gasses released into the atmosphere [3,4]. Research works also suggest that the intensive exploitation of arable lands for the production of plants intended for biofuels can adversely affect the global supply of food and cause a significant increase in food prices [5]. Hence, a strong need emerges to search for alternative biomass sources, the use of which for energy purposes would be justified from the economic and ecological perspective. Given the very high photosynthetic efficiency, the fast rate of biomass growth, resistance to various types of contaminants, and the possibility of management of lands that cannot be used for other purposes, algae seem to offer a perfect alternative to typical energy crops [6].

Most of the research works published so far have focused on bio-oil production technologies based on lipids accumulated in large amounts in algae cells. In the 1980s, the US Department of Energy launched a research program to identify the use of algae for energy production (the Aquatic Species Program). Scientists have analyzed over 3000 microalgae strains, trying to identify species with the highest energy potential [7]. In the following years, technologies for intensive algae cultivation in photobioreactors and biodiesel production were developed, and commercial biorefineries were launched, 
including among others, in Turkey and the United States of America $[8,9]$. Today, many research and implementation programs are in progress across the world, aiming to increase production efficiency of algae biomass and its conversion into biofuels. Several thousand patents related to the technologies of production, separation, and conversion of algae biomass into biofuels are registered annually, proving that this issue is still in the focus of researchers' interest.

There are a few reports in the literature on large-scale studies on the production of biohydrogen or biomethane from algal biomass. Installations for the production of algae biomass dedicated to the production of bio-oil are presented more frequently. For example, research by Muradel Pty Ltd. of Australia aimed at the production of biofuels, oleochemicals, biofertilizers, animal feed, and building materials in a raceway pond [10]. Sea6 Energy, India research was aimed at producing food additives, biofuel, bioplastic, and animal feed in sea water [11]. Production of astaxanthin and DHA in enclosed photobioreactors was carried out by Solix Algadrients Inc., USA [12]. Design and validation of a new integrated "biowaste-to-energy" concept involving algae cultivation and biogas production was carried out by the Technical Research Center of Finland [13].

Recently, many research groups work on improvement of microalgae biomass production methods. New technologies are developed such as the use of alternative source of phosphorus in order to control the contamination, for example the use phosphite deydrogenase (PtXD) that catalyzes the conversion of phosphite in phosphate [14]. Many Chlamydomonas strains have been produced expressing nuclear or chloroplastic PtxD [15,16]. There are many works in literature in which new strategies in tuning photosynthesis are developed. For example, by reducing chlorophyll content of Chlorella vulgaris strains in order to improve the light capture within the inner layers of the mass culture and control the cell-shading [17]. Moreover, strains that are able to resist in light-stress conditions by increasing the amount of carotenoids have also been developed $[18,19]$. This paper presents the possibility of using algae biomass to produce liquid and gaseous biofuels, including bio-oil, biohydrogen, and biogas.

\section{Bio-Oil Production}

Literature data show that over $19,000 \mathrm{dm}^{3}$ of bio-oil can be produced annually from one hectare of microalgae cultivation. For comparison, the oil production yield of other plants is much lower, like, e.g., palm oil-6100 $\mathrm{dm}^{3} /$ ha/year; sugar cane$4300 \mathrm{dm}^{3}$ / ha/year; maize-2400 $\mathrm{dm}^{3} /$ ha/year; or soybeans-500 dm $/$ ha/year [20,21].

The proliferation of microalgae as well as the content and composition of oil in cell dry matter depend on the conditions of their cultivation and the species used [22]. There are many classifications of technologies used in microalgae cultivation for oil. The most important is the one based on the nature of the biochemical processes ensuring intensive biomass growth and the effective production of lipid compounds. Considering this criterion, four main types of culture can be distinguished, namely: photoautotrophic, heterotrophic, mixotrophic, and photoheterotrophic [22].

Photoautotrophic microalgae use light, carbon dioxide, and water to biomass production [23]. This kind of cultivation is usually used for microalgae cultivation in large scale [24]. It was proven to result in high variance of the lipid content in the microalgae biomass, ranging from $5 \%$ to $68 \%$, depending on the strain used. In the case of the Chaetoceros calcitrans CS 178 strain, the lipid synthesis rate was $17.6 \mathrm{mg} / \mathrm{dm}^{3} \times \mathrm{d}$ and the final lipid concentration was $39.8 \%$ of cell dry matter [20]. On the other hand, the use of the Botryococcus braunii UTEX 572 strain allowed achieving culture yield at $5.5 \mathrm{mg} / \mathrm{dm}^{3} \times \mathrm{d}$ [24]. The highest yield was found in studies that verified the effect of high $\mathrm{CO}_{2}$ concentrations on biomass productivity and lipid production in a culture with Chlorella sp. strain. In this culture variant, the final bio-oil concentration was at $32-34 \%$ of cell dry matter and the maximal rate of lipid production was at $179.8 \mathrm{mg} / \mathrm{dm}^{3} \times \mathrm{d}$ [25].

The research carried out so far have shown that limiting the source of nitrogen in photoautotrophic cultures increased the lipid content in cell dry matter [9]. The effective- 
ness of this technological treatment was proved during semi-continuous culture of the Auxenochlorella pyrenoidosa strain with a limited amount of nitrogen source in the medium and $\mathrm{pH}$ control using $\mathrm{CO}_{2}$ [26]. The cited study confirmed that limiting the nitrogen concentration and adjusting the $\mathrm{pH}$ value by dosing $\mathrm{CO}_{2}$ allowed achieving very high parameters of the lipid synthesis efficiency, which amounted to $115 \mathrm{mg} / \mathrm{dm}^{3} \times \mathrm{d}$. It was more than three times higher compared to the control culture conducted without this technological treatment.

An appropriate amount of carbon dioxide should be provided to the growing population of microalgae to obtain satisfactory technological effects in photoautotrophic cultures, including biomass production and lipids accumulation. In many cases, $\mathrm{CO}_{2}$ is delivered by simple diffusion from the atmosphere or through an aeration process, as exemplified in a study conducted by Han et al. (2013) [26]. However, given the low concentrations of this gas in the atmospheric air in intensively developing cultures, $\mathrm{CO}_{2}$ may minimize the expected technological effects. Therefore, it is reasonable to locate photoautotrophic systems for microalgae biomass production in the vicinity of the waste source of this gas [27]. An example of such a solution is the Seambiotic pilot installation built in 2006 in Israel, which uses waste $\mathrm{CO}_{2}$ from a coal-fired power plant. In this installation, algae are cultured in open ponds with a total area of $1000 \mathrm{~m}^{2}$, whereas a gas containing about $12 \% \mathrm{CO}_{2}$ is directly dispersed into the culture via diffusers. The final yield of this technological solution is $20 \mathrm{~g}$ of dry biomass $/ \mathrm{m}^{2} \times \mathrm{d}$ [28]. In turn, de Morais and Costa (2007) demonstrated that only certain strains, such as Tetradesmus obliquus, Parachlorella kessleri, and Arthrospira sp., were able to grow under conditions of high $\mathrm{CO}_{2}$ concentration approximating 18\% [29].

Likewise, bacteria and fungi, selected species of microalgae are capable of heterotrophic development using organic substances [22]. The heterotrophic culture eliminates the common problem of photoautotrophic systems related to the overgrowth of the surface of photobioreactors and self-shading of microalgae cells, which directly reduces the access of light imperative for effective photosynthesis, biomass proliferation, and bio-oil production [23]. Heterotrophic algae cultivation systems are characterized by an efficient growth rate and the closing concentrations of biomass and lipids compared to the phototrophic or mixotrophic ones (Table 1). For example, the heterotrophic cultivation of Crypthecodinium cohnii in a medium consisting of glucose, yeast extract, and acetic acid ensured a dry biomass concentration of $109 \mathrm{~g} / \mathrm{dm}^{3}$ and a final lipid concentration of $61 \mathrm{~g} / \mathrm{dm}^{3}$ [30]. For some microalgae strains, a change in the cultivation conditions from photoautotrophic to heterotrophic increased the lipid concentration of the cell dry matter. For instance, a $40 \%$ increase in lipid content was achieved in the culture of Auxenochlorella protothecoides after modifying the culture conditions from phototrophic to heterotrophic [31]. In the case of C. vulgaris ESP-31 strain, the same modification caused an over ten-fold reduction in the biomass concentration [32].

Previous studies have shown that microalgae can assimilate organic carbon from various sources, including acetate, fructose, glucose, lactose, glycerol, sucrose, galactose, and mannose [33]. The possibility of using various organic compounds in the heterotrophic culture was described by De Swaaf (2003), who applied a protocol for acetic acid addition and culture $\mathrm{pH}$ control when multiplying the Crypthecodinium cohnii strain. This technological solution allowed obtaining very high values of final yield indicators, i.e., the concentration of cell dry matter in the culture at $109 \mathrm{~g} / \mathrm{dm}^{3}$ and the final lipid concentration in the culture at $61 \mathrm{~g} / \mathrm{dm}^{3}$ [30]. Another research proved that Auxenochlorella protothecoides strain grew in a batch reactors on media with technical glycerin as the only carbon source, reaching the final biomass concentration of $23.5 \mathrm{~g} / \mathrm{dm}^{3}$ and the bio-oil concentration of $14.6 \mathrm{~g} / \mathrm{dm}^{3}$ after 6 days of cultivation. In turn, using the semi-continuous culture strategy permitted growing the oil synthesis rate to $3 \mathrm{~g} / \mathrm{m}^{3} \times \mathrm{d}$ [34].

Currently, the possibilities of using cheaper sources of organic carbon to produce algae with a high lipid concentration in the cells, e.g., corn powder hydrolysate instead of glucose, are sought and investigated [31]. Using this organic substrate in a batch culture, Xiong et al. (2008) obtained the average lipid synthesis efficiency at $3.7 \mathrm{~g} / \mathrm{dm}^{3} \times \mathrm{d}$ [35] 
Other experiments proved that using a relatively expensive raw material, i.e., glucose, and controlling the oxygen transfer coefficient in Schizochytrium sp. HX-308 culture increased the production capacity of oily marine fungus, leading to a final biomass concentration of $92.72 \mathrm{gd} . \mathrm{m} . / \mathrm{dm}^{3}$ and the final DHA concentration of $17.7 \mathrm{~g} / \mathrm{dm}^{3}$ [36]. On the other hand, one of the highest reported final concentrations of microalgae cells in a culture $\left(171.5 \mathrm{~g}_{\mathrm{d} . \mathrm{m} .} / \mathrm{dm}^{3}\right)$, was obtained by Bailey et al. (2003) during the heterotrophic culture of Schizochytrium sp. ATCC20888 [37].

Table 1. Dry biomass and lipid production yields in various culture types [38].

\begin{tabular}{|c|c|c|c|c|}
\hline Microalgae Species & Culture Type & $\begin{array}{l}\text { Biomass Production } \\
\text { Yield }\left(\mathrm{g}_{\mathrm{d} . \mathrm{m} .} / \mathrm{dm}^{3} \times \mathrm{d}\right)\end{array}$ & $\begin{array}{l}\text { Lipid Production Yield } \\
\left(\mathrm{mg} / \mathrm{dm}^{3} \times \mathrm{d}\right)\end{array}$ & References \\
\hline Chaetoceros muelleri F\&M-M43 & Phototrophic & 0.07 & 21.8 & [20] \\
\hline Mychonastes homosphaera UTEX 2341 & Phototrophic & $0.02-0.03$ & $9.0-10.2$ & [39] \\
\hline Auxenochlorella protothecoides & Heterotrophic & $4.0-4.4$ & $1881.3-1840.0$ & [40] \\
\hline Auxenochlorella protothecoides & Heterotrophic & 2.0 & 932.0 & [31] \\
\hline Chlorella vulgaris \#259 & Mixotrophic & $0.09-0.25$ & $22.0-54.0$ & [33] \\
\hline Tetradesmus obliquus & Mixotrophic & $0.10-0.51$ & $11.6-58.6$ & [8] \\
\hline Scenedesmus quadricauda & Phototrophic & 0.19 & 35.1 & {$[20]$} \\
\hline Phaeodactylum tricornutum F\&M-M40 & Phototrophic & 0.24 & 44.8 & {$[20]$} \\
\hline Scenedesmus sp. DM & Phototrophic & 0.26 & 53.9 & [20] \\
\hline Scenedesmus sp. F\&M-M19 & Phototrophic & 0.21 & 40.8 & [20] \\
\hline Skeletonema costatum CS 181 & Phototrophic & 0.08 & 17.4 & [20] \\
\hline Tetraselmis suecica F\&M-M33 & Phototrophic & 0.32 & 27.0 & {$[20]$} \\
\hline Nannochloropsis sp. F\&M-M29 & Phototrophic & 0.17 & 37.6 & [20] \\
\hline Chlorella vulgaris CCAP $211 / 11 B$ & Phototrophic & 0.17 & 32.6 & [20] \\
\hline Tetradesmus obliquus & Phototrophic & 0.06 & 7.14 & [8] \\
\hline Rebecca salina CS 49 & Phototrophic & 0.16 & 49.4 & {$[20]$} \\
\hline Thalassiosira pseudonana CS 173 & Phototrophic & 0.08 & 17.4 & [20] \\
\hline
\end{tabular}

The highest efficiency of lipid biosynthesis obtained from the heterotrophic culture was several times higher than from the phototrophic culture (Table 1). The disadvantages of the heterotrophic culture include frequent contamination with other microorganisms, which diminishes the efficiency of this technological solution and, in some cases, inhibits the biochemical process [31]. This phenomenon was presented by Zhang et al. (2012), who studied the effect of bacteria on biomass and bio-oil production efficiency in a heterotrophic cultivation of Auxenochlorella pyrenoidosa with post-process wastewater from soybean processing used as a culture medium. In contrast, bacteria improved the degradation rates of nitrogen and phosphorus compounds and reduced the chemical oxygen demand of the culture, although they decreased the final concentrations of microalgae biomass and lipids [41]. The heterotrophic infections of microalgae cultures can be prevented by the addition of antibiotics, e.g., chloramphenicol, to the culture medium [42].

In the mixotrophic culture, photosynthesis proceeds in microalgae cells that consume carbon from both organic and inorganic sources [33]. Microalgae assimilate organic compounds, while $\mathrm{CO}_{2}$ released as a result of respiration is retained and reused as a substrate in the photosynthesis process [9]. Compared to the phototrophic and heterotrophic cultures, the mixotrophic culture is rarely used to produce bio-oil from microalgae (Table 1). This technological solution was used by Bhatnagar et al. (2011), who analyzed the production of Chlamydomonas globosa, Mychonastes homosphaera, and Scenedesmus bijugus. The addition of $1 \%(w / v)$ glucose to the cultures of Chlamydomonas globosa, Mychonastes homosphaera, and Scenedesmus bijugus caused a 9.4-, 6.7-, and 5.8-fold increase in the biomass production efficiency in the mixotrophic process compared to phototrophic culture as well as 3.0-, 2.0-, and 4.4-fold increase compared to the heterotrophic cultivation system [43]. Similar research results were obtained by Yu et al. (2009), who proved that the highest rate of Nostoc flagelliforme strain biomass growth was obtained in a mixotrophic culture with glucose addition, which proved to be 5.0 and 2.3 times more efficient than the phototrophic and heterotrophic culture, respectively [44].

Although the efficiency of oil production using microalgae largely depends on the strain used, the results presented in Table 1 confirm that the highest final technological 
effects, including biomass concentration in the system and lipid content in the cells, can be obtained in the heterotrophic culture. Thus, this culture method is of great interest to enterprise engaged in the implementation of bioenergy systems and investigation groups working on the development of such technologies [37]. The most severe disadvantage of the heterotrophic methods is the possibility of culture impurity with other microorganisms, which causes major problems in the operation of installations exploited on an industrial scale [42]. Moreover, the expense of a pure organic fertilizer makes that this culture type can only be used to produce metabolites with a high market value [45].

Photoautotrophic algal technology are the most frequently used ones. They offer a simple solution for cultivation scale enlargement through the use of open or hybrid bioreactors [46]. These cultures are promising because microalgae can use waste $\mathrm{CO}_{2}$, e.g., from heat and power plants, breweries, or anaerobic digesters [47]. However, the oil production yield they ensure is usually substantially lower than that achieved under heterotrophic culture conditions (Table 1). This is mainly due to slow cell growth and low biomass production efficiency. However, the lower costs of increasing the scale of this culture still make it very attractive for investors.

A characteristic feature of the photoheterotrophic culture is the use of light to ensure organic carbon fixation and degradation. The main difference between the mixotrophic and photoheterotrophic cultures is that the first uses organic compounds while the latter requires light as an energy source. Therefore, the photoheterotrophic culture requires both sugars and light at the same time [22]. Although the production of specific expensive secondary metabolites can be increased by using the photoheterotrophic culture, this solution is not employed for biodiesel production, as is the case with the mixotrophic microalgae culture [48].

\section{Biohydrogen Production}

Biohydrogen production carried out by microalgae is based on biophotolysis involving photosynthetic generation of hydrogen from water, in which light energy is necessary for the lysis of the water molecules into oxygen and hydrogen [49]. This process runs mainly due to hydrogenase, which catalyzes the oxidation of $\mathrm{H}_{2}$ and releases gaseous hydrogen by reducing protons [50]. Two transmembrane peptide complexes: photosystem I (PSI) and photosystem II (PSII), are responsible for hydrogen production by microalgae in the photolysis process. The water molecule breaks down due to the exposure of both complexes to solar radiation. Then, $\mathrm{O}_{2}$ is produced by PSII, while the electrons generated in this process are used by PSI to reduce $\mathrm{CO}_{2}$ and build cellular material (aerobic conditions), or transferred through ferredoxin to hydrogenase and used to produce hydrogen. The simultaneous initiation of hydrogen production and hydrogenase induction can proceed only under anaerobic conditions. In addition, reduced sulfur availability causes reversible inhibition of the PSII photosystem, which entails the simultaneous arrestment of the aerobic activity of photosynthesis. Under such conditions, the oxygen level drops below the value consumed by the respiratory system. However, the PSI photosystem, responsible for electron transfer through reduced ferredoxin to hydrogenase, remains active, enabling hydrogen production [51].

In the presence of organic substrates, the microalgae species capable of producing hydrogen can develop both in the light phase through mixotrophic growth, and in the dark one via heterotrophic transformations [52]. If the inflow of light energy to the cultivation system is limited, the available simple organic compounds are metabolized and used to satisfy cells' needs and synthesize biomass [53]. It has been proved that the most favorable conditions for hydrogen production in cell systems are when the oxygen content in the medium is kept below $0.1 \%$ [54]. The deprivation of sulfur compounds in the culture medium is usually achieved via algae culture centrifugation, and then suspending the concentrated and liquid phase-free biomass in the medium, in which sulfur has been replaced with chlorine compounds [55]. The technological treatment based on centrifugation has been proved expensive, time-consuming, and leading to partial damage of the cellular 
material. An alternative solution is to dilute the culture medium, which directly reduces the sulfur concentration in the technological system. However, this method extends the time needed for sulfur depletion and development of anaerobic conditions [56].

It is also challenging to determine culture time and to identify the onset of hydrogen production. Some authors state that the biomass production process should be carried out to half of the exponential growth phase [57]. Others argue that a higher density of algae cells directly improves efficiency and prolongs hydrogen production [58]. Ji et al. (2010) achieved hydrogen production at $16 \mathrm{~cm}^{3} / \mathrm{g}$ biomass with a cell density of $0.5 \mathrm{~g} / \mathrm{dm}^{3}$. When the cell density increased to $3.2 \mathrm{~g} / \mathrm{dm}^{3}$, they reported hydrogen production over $49 \mathrm{~cm}^{3} / \mathrm{g}$ biomass and simultaneous photochemical conversion at $0.3 \%$. The increased substrate density was also accompanied by an almost 10-fold increase in the gas production rate [58].

Most scientific publications addressing this research issue indicate the high efficiency of $\mathrm{H}_{2}$ production by unicellular algae, like Chlamydomonas reinchardtii commonly found in soil and saline waters [59]. The $\mathrm{H}_{2}$ production by this species was reported to reach 90-110 $\mathrm{cm}^{3} / \mathrm{dm}^{3}$ [56] and, in some cases, even $80-140 \mathrm{~cm}^{3} / \mathrm{dm}^{3}$ [60]. Faraloni et al. (2011) achieved a hydrogen production of $150 \mathrm{~cm}^{3} / \mathrm{dm}^{3}$ from the Chlamydomonas reinwardtii algae culture, using waste from olive processing in the algae growth process [61]. In turn, Skjanes et al. (2008) investigated the possibility of producing hydrogen from 21 species of green algae isolated from an anaerobic environment. They achieved the best production results for: Chlamydomonas reinhardtii, Chlamydomonas euryale, Chlamydomonas noctigama, Chlamydomonas vectensis, Auxenochlorella protothecoides, Oocystis, Desmodesmus subspicatus, and Raphidocelis subcapitata. The highest $\mathrm{H}_{2}$ production efficiency approximating $140 \mathrm{~cm}^{3} / \mathrm{dm}^{3}$ was demonstrated for Chlamydomonas reinhardtii, followed by Chlamydomonas noctigama $\left(80 \mathrm{~cm}^{3} / \mathrm{dm}^{3}\right)$ and Chlamydomonas euryale $\left(22 \mathrm{~cm}^{3} / \mathrm{dm}^{3}\right)[60]$.

The algae of the genus Chlorella sp. represent a taxon with a significant potency for hydrogen production [62]. This species' preponderance is due to its eurybiontic character, high adaptability to changing environmental conditions, resistance to pollution, and a fast growth rate [63]. Scientific research have confirmed the effective use of Chlorella sp. biomass in the hydrogen production process at a level comparable to other species of algae widely used in this technology [64]. Zhang et al. (2014) investigated hydrogen production by Auxenochlorella protothecoides algae species as affected by nutrient depletion in the culture medium, and achieved production efficiency at $110.8 \mathrm{~cm}^{3} / \mathrm{dm}^{3}$ of culture. Reduced concentrations of two components in the culture medium, namely nitrogen and sulfur, caused the hydrogen production efficiency to increase to the value of $140.4 \mathrm{~cm}^{3} / \mathrm{dm}^{3}$ of culture [65]. In turn, Chader et al. (2009) compared three species of algae: Chlorella sorokiniana, Chlorella salina, and Chlorella sp., for their hydrogen production capability and tolerance to oxygen. The research showed the highest hydrogen production by $C$. sorokiniana reaching $147 \mathrm{~cm}^{3}$ within $220 \mathrm{~h}$ of the experiment. However, these algae showed a low tolerance to the oxygen content in the medium, up to the level of $2 \%$. The remaining two microorganisms showed by lower hydrogen productivity and tolerance to oxygen concentrations from 11 to 15.4\% [66]. Song et al. (2011) achieved hydrogen production by Chlorella sp. from 260 to $480 \mathrm{~cm}^{3} / \mathrm{dm}^{3}$. The highest technological effects ranging from 183 to $238 \mathrm{~cm}^{3} / \mathrm{dm}^{3} \cdot \mathrm{h}$ were achieved at $37-40{ }^{\circ} \mathrm{C}$, with the initial glucose concentration of $30 \mathrm{mM}$ [64]. It has been proven that genetic modifications of Chlorella sp. algae allowed the hydrogen production process to be carried out without the need to ensure variable aerobicanaerobic conditions and remove sulfur compounds from the culture medium $[67,68]$. Amutha and Murugesan (2011) investigated hydrogen production by Chlorella vulgaris MSU 01 algae using various carbon sources in algae growth and hydrogen production processes, including corn stalks. The highest algae biomass growth was achieved using corn stalks as the carbon source at a concentration of $4 \mathrm{~g}$.m. $/ \mathrm{dm}^{3}$. The proliferated biomass was used for the hydrogen production process in a $0.5 \mathrm{dm}^{3}$ bioreactor. It ensured production yield at ca. $220 \mathrm{~cm}^{3} / \mathrm{dm}^{3}$ of culture after 6 days of the experiment. The average hydrogen production rate was $26 \mathrm{~cm}^{3} / \mathrm{dm}^{3} \cdot \mathrm{d}$ [62] . 
Other works have presented the results of research on the use of Tetraselmis subcordiformis in biohydrogen production under cyclical light and dark conditions and with an external carbon source, like e.g., acetate, glucose, sucrose, or other simple sugars. The average hydrogen production efficiency ranged from 78 to even $158 \mathrm{~cm}^{3} / \mathrm{dm}^{3}$ of the culture $[69,70]$. Ji et al. (2010) obtained the total production of hydrogen from Tetraselmis subcordiformis algae of $236.6 \mathrm{~cm}^{3}$ at a cell density of $3.2 \mathrm{~g} / \mathrm{dm}^{3}$. The production efficiency was $49.2 \mathrm{~cm}^{3} / \mathrm{g} \cdot \mathrm{h}$ with the maximum production rate of $7.20 \mathrm{~cm}^{3} / \mathrm{h}$ [58]. In turn, Ji et al. (2011) presented hydrogen production by Tetraselmis subcordiformis depending on the depletion of individual nutrients, such as nitrogen, sulfur, and phosphorus, in the culture medium. The research confirmed that the experimental variant with nitrogen compounds deficiency ensured the highest production efficiency, reaching $55.8 \mathrm{~cm}^{3} / \mathrm{dm}^{3}$ of culture. Due to the fast growth rate and ease of use of the systems for its biomass multiplication, this species seems an interesting substrate to produce organic substrate and hydrogen [71]. There is an increasing number of studies on the use of this microalgae species as a direct product in technologies aimed at producing energy carriers [69,70].

The efficiency of biohydrogen production by microalgae, reported in various works, is presented in Table 2 [72].

Table 2. Comparison of literature data on the efficiency of biohydrogen production by microalgae [62].

\begin{tabular}{ccc}
\hline Microalgae Species & Efficiency of Biohydrogen Production & References \\
\hline Tetraselmis subcordiformis & $157.7 \mathrm{~cm}^{3} / \mathrm{dm}^{3}$ & {$[58]$} \\
Tetraselmis subcordiformis & $50.0 \mathrm{~cm}^{3} / \mathrm{dm}^{3}$ & {$[70]$} \\
Tetraselmis subcordiformis & $55.8 \mathrm{~cm}^{3} / \mathrm{dm}^{3}$ & {$[71]$} \\
Chlamydomonas reinhardtii & $210.9 \mathrm{~cm}^{3} / \mathrm{dm}^{3}$ & {$[73]$} \\
Chlamydomonas reinhardtii & $120.0 \mathrm{~cm}^{3} / \mathrm{dm}^{3}$ & {$[60]$} \\
Chlamydomonas reinhardtii & $321.0 \mathrm{~cm}^{3} / \mathrm{dm}^{3}$ & {$[55]$} \\
Chlamydomonas reinhardtii & $180.0 \mathrm{~cm}^{3} / \mathrm{dm}^{3}$ & {$[56]$} \\
Chlorella sp. & $7.13 \mathrm{~cm}^{3} / \mathrm{g}_{\mathrm{o} . \mathrm{m} . \mathrm{m}}$ & {$[74]$} \\
\hline
\end{tabular}

Other biological reaction used by algae to hydrogen synthesis is through the indirect biophotolysis. It proceeds in the organisms of cyanobacteria, which via photosynthesis accumulate carbohydrates resulting from $\mathrm{CO}_{2}$ reduction. In turn, these carbohydrates are degraded by fermentation. The indirect biophotolysis proceeds with the involvement of photosystem I. The proteins it contains transfer electrons to ferredoxin using light energy [75]. A significant role is also played by $\mathrm{CO}_{2}$, which is a carrier of electrons and protons formed during water molecule degradation, and by enzymes, including two NiFe hydrogenases and nitrogenase. The latter catalyzes the reaction of atmospheric nitrogen reduction to ammonia, which is accompanied by proton reduction and hydrogen release, according to Equation (1) [76]:

$$
\mathrm{N}_{2}+8 \mathrm{H}^{+}+8 e^{-}+16 \mathrm{ATP} \rightarrow 2 \mathrm{NH}_{3}+\mathrm{H}_{2}+16 \mathrm{ADP}+16 \mathrm{P}_{i}
$$

Nitrogenase can also reduce protons to molecular hydrogen, according to Equation (2):

$$
2 \mathrm{H}^{+}+2 e^{-}+4 A T P \rightarrow \mathrm{H}_{2}+4 A D P+4 P_{i}
$$

Cyanobacteria represent a very promising taxonomic group that can be used to produce hydrogen. Their advantages include susceptibility to genetic modifications, small environmental requirements, and no need for the delivery of specific nutrients to the technological system [77].

The experiments described by Troshina et al. (2002) [78] are examples of research in which Cyanobacteria biomass was used to produce hydrogen. In this particular research, the authors used the population of Gloeocapsa alpicola Calu 743 grown under limited access to nitrates, which was expected to promote hydrogen production. An intense $\mathrm{H}_{2}$ 
production was observed, reaching $25 \mu \mathrm{L} / \mathrm{h}$ per mg dry matter, due to the biodegradation of glycogen accumulated in cells during the photoautotrophic growth period. Similar research was also conducted by Aoyama et al. (1997), who used the filamentous strain of cyanobacteria Arthrospira platensis NIES-46, and reported hydrogen production efficiency approximating $2 \mu \mathrm{mol} / \mathrm{mg}$ dry matter. Apart from hydrogen, the products of the process included ethanol and low molecular weight organic acids, mainly acetic acid [79]. In turn, Khetkorn et al. (2010) analyzed the potential of Cylindrospermum siamense TISTR8012 strain of cyanobacteria for hydrogen production. In this experiment, $0.5 \%$ fructose was introduced into the technological system as an exogenous carbon source to intensify biochemical conversion, and continuous access of light was ensured at $200 \mu \mathrm{E} / \mathrm{m}^{2} \cdot \mathrm{s}$. These conditions allowed achieving hydrogen production efficiency at $32 \mu \mathrm{mol} / \mathrm{mg} \mathrm{Chl} \alpha \cdot \mathrm{h}$ [80]. In another of their works, these authors tested the same species of algae, obtaining a production rate of $29.7 \mu \mathrm{mol} / \mathrm{mg} \mathrm{Chl} \alpha \cdot \mathrm{h}$ [81].

\section{Biogas Production}

Research on the use of macroalgae in anaerobic digestion were analyzed by VergaraFernàndez [82]. He examined the possibility of using the Macrocystis pyrifera and Durvillaea antarctica biomass based on the blend of these species. His research showed that the yield of biogas production was similar and shaped on the level about $180.4 \pm 1.5 \mathrm{dm}^{3} / \mathrm{kg}_{\mathrm{d} . \mathrm{m}} . \times \mathrm{d}$. The use of the algae mixture directly impacted the lower efficiency of biogas production to $158.3 \mathrm{dm}^{3} / \mathrm{kg}_{\text {d.m. }} \times \mathrm{d}$. The concentration of $\mathrm{CH}_{4}$ ranged from $60.0 \%$ to $70.0 \%$ [82].

Singh and Gu [83] and Parmar et al. [84] analyzed the biogas production efficiency with phytobenthos biomass used as an organic matter. They achieved the highest efficiency during fermentation of Laminaria digitata belonging to the order Laminariales. In that case, methane generation reached $500 \mathrm{dm}^{3} \mathrm{CH}_{4} / \mathrm{kg}_{\text {o.d.m. }}$. The use of Macrocystis sp. enabled achieving $390-410 \mathrm{dm}^{3} \mathrm{CH}_{4} / \mathrm{kg}_{\text {o.d.m. }}$, whereas upon the use of Gracilaria sp. (Rhodophyta) and Laminaria sp. (Ochrophyta, Phaeophyceae) $\mathrm{CH}_{4}$ production was for $280-400 \mathrm{dm}^{3} \mathrm{CH}_{4} / \mathrm{kg}_{\text {o.d.m. }}$ and $260-280 \mathrm{dm}^{3} \mathrm{CH}_{4} / \mathrm{kg}_{\text {o.d.m. }}$. The lowest technological efficiency were observed in the digestion of Ulva sp., i.e., barely $200 \mathrm{dm}^{3} \mathrm{CH}_{4} / \mathrm{kg}_{\text {d.m. }}$ [83,84]. Investigation by Debowski et al. [85] proved that the effects of the anaerobic digestion of macroalgae from the Puck Bay were directly dependent on the organic load rate (OLR) used. The highest $\mathrm{CH}_{4}$ production $\left(240 \mathrm{dm}^{3} \mathrm{CH}_{4} / \mathrm{kg}_{\text {o.d.m. }}\right.$ ) was observed at the OLR from $1.0 \mathrm{~kg}$ to $2.0 \mathrm{~kg}$ o.d.m. $/ \mathrm{m}^{3} \times \mathrm{d}$. The higher OLR values had a direct negative effect on anaerobic digestion efficiency [85]. Yuan et al. [86] proved that $\mathrm{CH}_{4}$ generation in the digestion process of blue-green algae was $189.89 \mathrm{dm}^{3} \mathrm{CH}_{4} / \mathrm{kg}_{\text {o.d.m. }}$. Zeng et al. [87] analyzed the anaerobic digestion of Macrocystis sp. with liquid manure. The $\mathrm{CH}_{4}$ production was $153.66 \mathrm{dm}^{3} \mathrm{CH}_{4} / \mathrm{kg}_{\text {o.d.m. }}$. Other research examining the possibility of biogas production were carried out with, among others, Laminaria sp., Macrocystis sp. [88], Gracilariaceae [89], and Ulva sp. [90].

In an investigation conducted by Grala et al. [91], the anaerobic digestion was run with the biomass based on Pilayella (90\% contribution) and Ectocarpus ( $8 \%$ contribution) and sporadically occurring Ulva. The biomass was directed to enzymatic hydrolysis with a blend of the enzymes: Celluclast 1.5 L, Novozym 188, and Hemicellulase, and to the process of hydrothermal depolymerization run for $120 \mathrm{~min}$ at a temperature of $200{ }^{\circ} \mathrm{C}$ under the pressure of $17 \mathrm{Ba}$. Biogas production was 40 and $54.0 \mathrm{dm}^{3} / \mathrm{kg}$ substrate in the most effective variants. The $\mathrm{CH}_{4}$ concentration was about $73.0 \%$. The biogas production efficiency with macroalgae used as a substrate in methane fermentation processes is presented in Table 3. 
Table 3. Efficiency of biogas production with the use of macroalgae as a substrate in methane fermentation processes.

\begin{tabular}{ccc}
\hline Macroalgae Taxon & Quantity of Biogas/Methane & References \\
\hline Macrocystis pyrifera & $181.4 \pm 52.3 \mathrm{dm}^{3} \mathrm{CH}_{4} / \mathrm{kg}_{\mathrm{d} . \mathrm{m} .} \times \mathrm{d}$ & {$[44]$} \\
M. pyrifera+Durvillaea antarctica & $164.2 \pm 54.9 \mathrm{dm}^{3} \mathrm{CH}_{4} / \mathrm{kg}_{\mathrm{d} . \mathrm{m} .} \times \mathrm{d}$ & {$[44]$} \\
D. antarctica & $179.3 \pm 80.2 \mathrm{dm}^{3} \mathrm{CH}_{4} / \mathrm{kg}_{\mathrm{d} . \mathrm{m} .} \times \mathrm{d}$ & {$[44]$} \\
Laminaria sp. & $260-280 \mathrm{dm}^{3} / \mathrm{kg}_{\text {o.d.m. }}$ & {$[87,88]$} \\
Gracilaria sp. & $280-400 \mathrm{dm}^{3} / \mathrm{kg}_{\text {o.d.m. }}$ & {$[87,88]$} \\
Macrocystis & $390-410 \mathrm{dm}^{3} / \mathrm{kg}_{\text {o.d.m. }}$ & {$[87,88]$} \\
Laminaria digitata & $500 \mathrm{dm}^{3} / \mathrm{kg}_{\text {o.d.m. }}$ & {$[87,88]$} \\
Ulva sp. & $200 \mathrm{dm}^{3} / \mathrm{kg}_{\text {o.d.m. }}$ & {$[87,88]$} \\
Macrocystis sp. & $189.9 \mathrm{dm}^{3} \mathrm{CH}_{4} / \mathrm{kg}_{\text {o.d.m. }}$ & {$[43]$} \\
Ulva lactuca & $157-271 \mathrm{dm}^{3} \mathrm{CH}_{4} / \mathrm{kg}_{\text {o.d.m. }}$ & {$[33]$} \\
Pilayella+Ectocarpus + Ulva & $40.0-54.0 \mathrm{dm}^{3} / \mathrm{kg}_{29.2-39.4 \mathrm{dm} \mathrm{CH}_{4} / \mathrm{kg}}^{[40]}$ & \\
\hline
\end{tabular}

The first investigations of anaerobic digestion of microalgae based on Chlorella sp. and Scenedesmus sp. biomass were conducted by Golueke et al. [92]. They compared the efficiency of the anaerobic digestion of algae and wastewater sludge. The efficiency of the fermentation of sewage sludge reached $1020 \mathrm{dm}^{3} / \mathrm{kg}_{\text {o.d.m. }}$, whereas for algae biomass it

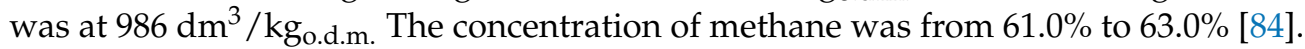

Zamalloa et al. [93] investigated the possibility of fermenting Tetradesmus obliquus, Phaeodactylum tricornutum, and Arthrospira platensis. After 30 days of incubation, they achieved $210 \pm 3.0 \mathrm{dm}^{3} \mathrm{CH}_{4} / \mathrm{kg}_{\text {o.d.m. }}$ in the case of T. obliquus and $350 \pm 3.0 \mathrm{dm}^{3} \mathrm{CH}_{4} / \mathrm{kg}$ o.d.m. in the variant with P. tricornutum biomass. By comparison, in the fermentation process of S. platensis, the methane production yield reached $280 \pm 0.8 \mathrm{dm}^{3} \mathrm{CH}_{4} / \mathrm{kg}$ o.d.m. In turn, Mussgnug et al. [94] tested six species of phytoplankton, i.e.,: Chlamydomonas reinhardtii, Dunaliella salina, and T. obliquus, Parachlorella kessleri, Euglena gracilis and bluegreen algae Arthrospira platensis. The anaerobic digestion of $C$. reinhardtii resulted at $587 \pm 8.8 \mathrm{dm}^{3} / \mathrm{kg}_{\text {o.d.m. }}, D$. salina at $505 \pm 24.8 \mathrm{dm}^{3} / \mathrm{kg}_{\text {o.d.m. }}$. of biogas. The biogas production in anaerobic degradation used to $A$. platensis and $E$. gracilis resulted at $481 \pm 13.8 \mathrm{dm}^{3} / \mathrm{kg}_{\text {o.d.m. }}$ and $485 \pm 3.0 \mathrm{dm}^{3} / \mathrm{kg}_{\text {o.d.m. }}$ respectively. Biogas production from the biomass of P. kessleri and T. obliquus algae was $335 \pm 7.8 \mathrm{dm}^{3} / \mathrm{kg}_{\text {o.d.m. }}$. and $287 \pm$ $10.1 \mathrm{dm}^{3} / \mathrm{kg}_{\text {o.d.m., }}$ respectively [94]. Authors state that anaerobic digestion efficiency was not dependent on the taxonomic group of algae. The main determination of the biogas amount and $\mathrm{CH}_{4}$ concentration was feasible upon individual verification of experiments for each of the analyzed species.

Literature present a correlation between the structure of cells of the microalgae biomass and susceptibility to degradation in anaerobic reactors and efficiency of biogas production. The high biogas production was observed when algae with no cell wall, as in the case of $D$. salina [95], or their cell wall did not contain cellulose and hemicellulose components and was made of protein substances, as in the case of C. reinhardtii [96], A. platensis [97], and E. gracilis [98]. Contrary to the aforementioned species, P. kessleri and T. obliquus have cell walls built of hemicellulose $[99,100]$. The cell wall of T. obliquus is described in the literature as especially difficult to break owing to the presence of a sporopollenin biopolymer [101]. Even more complex is the silica structure of the cell wall of Bacillariophyceae [102].

\section{Conclusions}

Although very prospective, biofuels' production from algae biomass is characterized by many limitations that must be verified in installations operating in a technical scale. Unfortunately, most of the research works had been carried out under laboratory conditions, rarely on a fractional-technical scale. This significantly curbs the possibility of obtaining reliable data for a comprehensive evaluation of the technological, environmental, and economic efficiency of these technological solutions. Their analysis is also made difficult because authors present contradictory opinions on the efficiency of microalgae biomass production and the actual yields of such solutions. 
Among all the directions of using algae biomass for biofuel purposes, the conversion of algae biomass to biogas is indicated as a highly profitable and economically justified technological solution. Next to biogas, it results in the production of post-digestion sludge, which can be used as a fertilizer for arable crops or, after processing, returned to the algae cultivation photobioreactors as a medium component. Many researchers claim that using the methane fermentation process carried out under appropriate conditions as the most important method for algae biomass conversion determines a higher economic effect compared to the integrated system of lipid extraction and anaerobic processing of post-extraction residues. Other results suggest that the balance of unit operations carried out in the methane fermentation process is the most effective both in terms of economic analysis and emission of pollutants to elements of the natural environment. The research results prove that methane fermentation may be the most practical way of converting algae biomass into energy. At the same time, it was found that energy inputs and environmental effects were highly diverse, depending on the technological solution used in the methane fermentation process. Therefore, for a complete and objective assessment, it is necessary to carry out an environmental life cycle assessment (LCA) in each case.

Author Contributions: Conceptualization, M.D. and M.Z.; methodology, M.D.; validation, M.Z. and I.Ś.; formal analysis, M.D. and M.Z.; investigation, M.D., M.Z., and J.K.; resources, M.D., I.Ś., and J.K.; data curation, M.D. and I.S.; writing—original draft preparation, M.D. and J.K.; writingreview and editing, M.D., M.Z., I.Ś., and J.K.; visualization, M.D. and J.K.; supervision, M.D.; project administration, M.Z.; funding acquisition, M.D. and J.K. All authors have read and agreed to the published version of the manuscript.

Funding: The manuscript was supported by Project financially supported by Minister of Education and Science in the range of the program entitled "Regional Initiative of Excellence" for the years 2019-2022, project no. 010/RID/2018/19, amount of funding: 12,000,000 PLN, and the work WZ/WBIIŚ/2/2019, funded by the Minister of Education and Science.

Institutional Review Board Statement: Not applicable.

Informed Consent Statement: Not applicable.

Data Availability Statement: Not applicable.

Conflicts of Interest: The authors declare no conflict of interest.

\section{References}

1. Goyal, H.B.; Seal, D.; Saxena, R.C. Bio-fuels from thermochemical conversion of renewable resources: A review. Renew. Sustain. Energy Rev. 2008, 12, 504-517. [CrossRef]

2. Börjesson, P.; Berglund, M. Environmental systems analysis of biogas systems -part I: Fuel-cycle emissions. Biomass Bioenergy 2006, 30, 469-485. [CrossRef]

3. Fargione, J.; Hill, J.; Tilman, D.; Polasky, S.; Hawthorne, P. Land clearing and the biofuel carbon debt. Science 2008, 319, 1235-1238. [CrossRef] [PubMed]

4. Searchinger, T.; Heimlich, R.; Houghton, R.; Dong, F.; Elobeid, A.; Fabiosa, J.; Tokgoz, S.; Hayes, D.; Yu, T. Use of us croplands for biofuels increases greenhouse gases through emissions from land-use change. Science 2008, 319, 1238-1240. [CrossRef] [PubMed]

5. Johansson, D.; Azar, C. A Scenario based analysis of land competition between food and bioenergy production in the us. Clim. Chang. 2007, 82, 267-291. [CrossRef]

6. Smith, V.; Sturm, B.; deNoyelles, F.; Billings, S. The ecology of algal biodiesel production. Trends Ecol. Evol. 2010, 25, 301-309. [CrossRef]

7. Sheehan, J.; Dunahay, T.; Benemann, J.; Roessler, P. A Look Back at the Us Department of Energy's Aquatic Species Program-Biodiesel from Algae; The National Renewable Energy Laboratory: Golden, CO, USA, 1998.

8. Mandal, S.; Mallick, N. Microalga Scenedesmus obliquus as a potential source for biodiesel production. Appl. Microbiol. Biotechnol. 2009, 84, 281-291. [CrossRef]

9. Mata, T.M.; Martins, A.A.; Caetano, N.S. Microalgae for biodiesel production and other applications: A review. Renew. Sustain. Energy Rev. 2010, 14, 217-232. [CrossRef]

10. Duong, V.T.; Li, Y.; Nowak, E.; Schenk, P.M. Microalgae Isolation and Selection for Prospective Biodiesel Production. Energies 2012, 5, 1835-1849. [CrossRef]

11. Wei, N.; Quarterman, J.; Jin, Y.S. Marine macroalgae: An untapped resource for producing fuels and chemicals. Trends Biotechnol. 2013, 31, 70-77. [CrossRef] [PubMed] 
12. Radakovits, R.; Jinkerson, R.E.; Fuerstenberg, S.I.; Tae, H.; Settlage, R.E.; Boore, J.L.; Posewitz, M.C. Draft genome sequence and genetic transformation of the oleaginous alga Nannochloropis gaditana. Nat. Commun. 2012, 3, 686. [CrossRef]

13. Schultz-Zehden, A.; Matczak, M. (Eds.) SUBMARINER Compendium: An Assessment of Innovative and Sustainable Uses of Baltic Marine Resources; Maritime Institute in Gdansk: Gdansk, Poland, 2012.

14. Hirota, R.; Motomura, K.; Kuroda, A. Biological Phosphite Oxidation and Its Application to Phosphorus Recycling. In Phosphorus Recovery and Recycling; Springer: Singapore, 2019; pp. 499-513. [CrossRef]

15. Changko, S.; Rajakumar, P.D.; Young, R.E.B.; Purton, S. The phosphite oxidoreductase gene, ptxD as a bio-contained chloroplast marker and crop-protection tool for algal biotechnology using Chlamydomonas. Appl. Microbiol. Biotechnol. 2020, 104, 675-686. [CrossRef]

16. Cutolo, E.; Tosoni, M.; Barera, S.; Herrera-Estrella, L.; Dall'Osto, L.; Bassi, R. A Phosphite Dehydrogenase Variant with Promiscuous Access to Nicotinamide Cofactor Pools Sustains Fast Phosphite-Dependent Growth of Transplastomic Chlamydomonas reinhardtii. Plants 2020, 9, 473. [CrossRef]

17. Nwoba, E.G.; Parlevliet, D.A.; Laird, D.W.; Alameh, K.; Moheimani, N.R. Light management technologies for increasing algal photobioreactor efficiency. Algal Res. 2019, 39, 101433. [CrossRef]

18. Maltsev, Y.; Maltseva, K.; Kulikovskiy, M.; Maltseva, S. Influence of Light Conditions on Microalgae Growth and Content of Lipids, Carotenoids, and Fatty Acid Composition. Biology 2021, 10, 1060. [CrossRef]

19. Shi, T.Q.; Wang, L.R.; Zhang, Z.X.; Sun, X.M.; Huang, H. Stresses as first-line tools for enhancing lipid and carotenoid production in microalgae. Front. Bioeng. Biotechnol. 2020, 8, 610. [CrossRef]

20. Rodolfi, L.; Zittelli, G.C.; Bassi, N.; Padovani, G.; Biondi, N.; Bonini, G.; Tredici, M.R. Microalgae for oil: Strain selection, induction of lipid synthesis and outdoor mass cultivation in a low-cost photobioreactor. Biotechnol. Bioeng. 2009, 102, 100-112. [CrossRef]

21. Schenk, P.M.; Thomas-Hall, S.R.; Stephens, E.; Marx, U.C.; Mussgnug, J.H.; Posten, C.; Kruse, O.; Hankamer, B. Second generation biofuels: High-efficiency microalgae for biodiesel production. Bioenergy Res. 2008, 1, 20-43. [CrossRef]

22. Chojnacka, K.; Marquez-Rocha, F.J. Kinetic and stoichiometric relationships of the energy and carbon metabolism in the culture of microalgae. Biotechnology 2004, 3, 21-34. [CrossRef]

23. Huang, G.H.; Chen, F.; Wei, D.; Zhang, X.W.; Chen, G. Biodiesel production by microalgal biotechnology. Appl. Energy 2010, 87, 38-46. [CrossRef]

24. Yoo, C.; Jun, S.Y.; Lee, J.Y.; Ahn, C.Y.; Oh, H.M. Selection of microalgae for lipid production under high levels carbon dioxide. Bioresour. Technol. 2010, 101, 71-74. [CrossRef] [PubMed]

25. Chiu, S.Y.; Kao, C.Y.; Chen, C.H.; Kuan, T.C.; Ong, S.C.; Lin, C.S. Reduction of $\mathrm{CO}_{2}$ by a high-density culture of Chlorella sp. in a semicontinuous photobioreactor. Bioresour. Technol. 2008, 99, 3389-3396. [CrossRef] [PubMed]

26. Han, S.J.; Bang, Y.; Yoo, J.; Kang, K.H.; Song, J.H.; Seo, J.G.; Song, I.K. Hydrogen production by steam reforming of ethanol over mesoporous NieAl2O3eZrO2 aerogel catalyst. Int. J. Hydrog. Energy 2013, 38, 15119-15127. [CrossRef]

27. Ryan, D.; Jennifer, M.; Christopher, K.; Nicholas, G.; Eric, T. Process Design and Economics for the Production of Algal Biomass: Algal Biomass Production in Open Pond Systems and Processing Through Dewatering for Downstream Conversion; NREL/TP-5100-64772; National Renewable Energy Lab. (NREL): Golden, CO, USA, 2016.

28. Zhang, X. Microalgae Removal of $\mathrm{CO}_{2}$ from Flue Gas; IEA Clean Coal Centre: London, UK, 2015.

29. De Morais, M.G.; Costa, J.A.V. Isolation and selection of microalgae from coal fired thermoelectric power plant for biofixation of carbon dioxide. Energy Convers. Manag. 2007, 48, 2169-2173. [CrossRef]

30. De Swaaf, M.E. Docosahexaenoic Acid Production by the Marine Alga Crypthecodinium cohnii. Doctoral Thesis, Delft University, Delft, The Nederlands, 2003.

31. Xu, H.; Miao, X.L.; Wu, Q.Y. High quality biodiesel production from a microalga Chlorella protothecoides by heterotrophic growth in fermenters. J. Biotechnol. 2006, 126, 499-507. [CrossRef]

32. Kuei-Ling, Y.; Jo-Shu, C. Effects of cultivation conditions and media composition on cell growth and lipid productivity of indigenous microalga Chlorella vulgaris ESP-31. Bioresour. Technol. 2012, 105, 120-127.

33. Liang, Y.; Sarkany, N.; Cui, Y. Biomass and lipid productivities of Chlorella vulgaris under autotrophic, heterotrophic and mixotrophic growth conditions. Biotechnol. Lett. 2009, 31, 1043-1049. [CrossRef]

34. Chen, Y.H.; Walker, T.H. Biomass and lipid production of heterotrophic microalgae Chlorella protothecoides by using biodieselderived crude glycerol. Biotechnol. Lett. 2011, 33, 1973-1983. [CrossRef]

35. Xiong, W.; Li, X.; Xiang, J.; Wu, Q. High-density fermentation of microalga Chlorella protothecoides in bioreactor for microbio-diesel production. Appl. Microbiol. Biotechnol. 2008, 78, 29-36. [CrossRef]

36. Qu, L.; Ji, X.J.; Ren, L.J.; Nie, Z.K.; Feng, Y.; Wu, W.J.; Ouyang, P.K.; Huang, H. Enhancement of docosahexaenoic acid production by Schizochytrium sp. using a two-stage oxygen supply control strategy based on oxygen transfer coefficient. Lett. Appl. Microbiol. 2010, 52, 22-27. [CrossRef]

37. Bailey, R.B.; Dimasi, D.; Hansen, J.M.; Mirrasoul, P.J.; Ruecker, C.M.; Veeder, G.T.; Kaneko, T.; Barclay, W.R. Enhanced production of lipids containing polyenoic fatty acid by very high density cultures of eukaryotic microbes in fermenters. U.S. Patent 6,607,900, 19 August 2003.

38. Dębowski, M.; Zieliński, M.; Kazimierowicz, J.; Kujawska, N.; Talbierz, S. Microalgae Cultivation Technologies as an Opportunity for Bioenergetic System Development-Advantages and Limitations. Sustainability 2020, 12, 9980. [CrossRef] 
39. Illman, A.M.; Scragg, A.H.; Shales, S.W. Increase in Chlorella strains calorific values when grown in low nitrogen medium. Enzym. Microb. Technol. 2000, 27, 631-635. [CrossRef]

40. Cheng, Y.; Zhou, W.G.; Gao, C.F.; Lan, K.; Gao, Y.; Wu, Q.Y. Biodiesel production from Jerusalem artichoke (Helianthus Tuberosus L.) tuber by heterotrophic microalgae Chlorella protothecoides. J. Chem. Technol. Biotechnol. 2009, 84, 777-781. [CrossRef]

41. Zhang, Y.; Su, H.; Zhong, Y.; Zhang, C.; Shen, Z.; Sang, W.; Yan, G.; Zhou, X. The effect of bacterial contamination on the heterotrophic cultivation of Chlorella pyrenoidosa in wastewater from the production of soybean products. Water Res. 2012, 46, 5509-5516. [CrossRef]

42. Marudhupandia, T.; Sathishkumara, R.; Kumara, T.T.A. Heterotrophic cultivation of Nannochloropsis salina for enhancing biomass and lipid production. Biotechnol. Rep. 2016, 10, 8-16. [CrossRef] [PubMed]

43. Bhatnagar, A.; Chinnasamy, S.; Singh, M.; Das, K.C. Renewable biomass production by mixotrophic algae in the presence of various carbon sources and wastewaters. Appl. Energy 2011, 88, 3425-3431. [CrossRef]

44. Yu, H.F.; Jia, S.R.; Dai, Y.J. Growth characteristics of the cyanobacterium Nostocflagelli for mein photoautotrophic, mixotrophic and heterotrophic cultivation. J. Appl. Phycol. 2009, 21, 127-133. [CrossRef]

45. Anand, P.; Saxena, R.K. A comparative study of solvent-assisted pretreatment of biodiesel derived crude glycerol on growth and 1,3-propanediol production from Citrobacter freundii. New Biotechnol. 2011, 29, 199-205. [CrossRef]

46. Jiang, Y.; Yoshida, T.; Quigg, A. Photosynthetic performance, lipid production and biomass composition in response to nitrogen limitation in marine microalgae. Plant Physiol. Biochem. 2012, 54, 70-77. [CrossRef] [PubMed]

47. Ho, S.H.; Chen, C.Y.; Chang, J.S. Effect of light intensity and nitrogen starvation on CO2 fixation and lipid/carbohydrate production of an indigenous microalga Scenedesmus obliquus CNW-N. Bioresour. Technol. 2012, 113, 244-252. [CrossRef]

48. Ogbonna, J.C.; Ichige, E.; Tanaka, H. Regulating the ratio of photoautotrophic to heterotrophic metabolic activities in photoheterotrophic culture of Euglena gracilis and its application to alpha-tocopherol production. Biotechnol. Lett. 2002, $24,953-958$.

49. Dasgupta, C.N.; Gilbert, J.J.; Lindblad, P.; Heidorn, T.; Borgvang, S.A.; Skjanes, K.; Das, D. Recent trends on the development of photobiological processes and photobioreactors for the improvement of hydrogen production. Int. J. Hydrog. Energy 2010, 35, 10218-10238. [CrossRef]

50. Miyake, J.; Miyake, M.; Asada, Y. Biotechnological hydrogen production: Research for efficient light energy conversion. J. Biotechnol. 1999, 70, 89-101. [CrossRef]

51. Ni, F.M.; Leung, D.Y.C.; Leung, M.K.H.; Sumathy, K. An overview of hydrogen production from biomass. Fuel Process. Technol. 2006, 87, 461-472. [CrossRef]

52. Kosourov, S.; Patrusheva, E.; Ghirardi, M.L.; Seibert, M.; Tsygankov, A. A comparison of hydrogen photoproduction by sulfurdeprived Chlamydomonas reinhardtii under different growth conditions. J. Biotechnol. 2007, 128, 776-787. [CrossRef]

53. Ogbonna, J.C.; Tanaka, H. Night Biomass Loss and Changes in Biochemical Composition of Cells during Light/Dark Cyclic Culture of Chlorella pyrenoidosa. J. Ferment. Bioeng. 1996, 82, 558-564. [CrossRef]

54. Tamburic, B.; Zemichael, F.W.; Maitland, G.C.; Hellgardt, K. Parameters affecting the growth and hydrogen production of the green alga Chlamydomonas reinhardtii. Int. J. Hydrog. Energy 2010, 36, 7872-7876. [CrossRef]

55. Oncel, S.; Vardar-Sukan, F. Photo-bioproduction of hydrogen by Chlamydomonas reinhardtii using a semi-continuous process regime. Int. J. Hydrog. Energy 2009, 34, 7592-7602. [CrossRef]

56. Laurinavichene, T.V.; Tolstygina, I.V.; Galiulina, R.R.; Ghirardi, M.L.; Seibert, M.; Tsygankov, A.A. Dilution methods to deprive Chlamydomonas reinhardtii cultures of sulfur for subsequent hydrogen photoproduction. Int. J. Hydrog. Energy 2002, 27, 1245-1249. [CrossRef]

57. Winkler, M.; Hemschemeier, A.; Gotor, C.; Melis, A.; Happe, T. [Fe]-hydrogenases in green algae: Photo-fermentation and hydrogen evolution under sulfur deprivation. Int. J. Hydrog. Energy 2002, 27, 1431-1439. [CrossRef]

58. Ji, C.F.; Legrand, J.; Pruvost, J.; Chen, Z.A.; Zhang, W. Characterization of hydrogen production by Platymonas Subcordiformis in torus photobioreactor. Int. J. Hydrog. Energy 2010, 35, 7200-7205. [CrossRef]

59. Vijayaraghavan, K.; Karthik, K.; Nalini, S.P.K. Hydrogen production by Chlamydomonas reinhardtii under light driven sulfur deprived condition. Int. J. Hydrog. Energy 2009, 34, 7964-7970. [CrossRef]

60. Skjanes, K.; Knutsen, G.; Källqvist, T.; Lindblad, P. $\mathrm{H}_{2}$ production from marine and freshwater species of green algae during sulfur deprivation and considerations for bioreactor design. Int. J. Hydrog. Energy 2008, 33, 511-521. [CrossRef]

61. Faraloni, C.; Ena, A.; Pintucci, C.; Tortillo, G. Enhanced hydrogen production by means of sulfur-deprived Chlamydomonas reinhardtii cultures grown in pretreated olive mill wastewater. Int. J. Hydrog. Energy 2011, 36, 5920-5931. [CrossRef]

62. Amutha, K.B.; Murugesan, A.G. Biological hydrogen production by the algal biomass Chlorella vulgaris MSU 01 strain isolated from pond sediment. Bioresour. Technol. 2011, 102, 194-199. [CrossRef] [PubMed]

63. Liu, C.H.; Chang, C.Y.; Liao, Q.; Zhu, X.; Chang, J.S. Photoheterotrophic growth of Chlorella vulgaris ESP6 on organic acids from dark hydrogen fermentation effluents. Bioresour. Technol. 2013, 145, 331-336. [CrossRef] [PubMed]

64. Song, W.; Rashid, N.; Choi, W.; Lee, K. Biohydrogen production by immobilized Chlorella sp. using cycles of oxygenic photosynthesis and anaerobiosis. Bioresour. Technol. 2011, 102, 8676-8681. [CrossRef]

65. Zhang, L.; He, M.; Liu, J. The enhancement mechanism of hydrogen photoproduction in Chlorella protothecoides under nitrogen limitation and sulfur deprivation. Int. J. Hydrog Energy 2014, 39, 8969-8976. [CrossRef]

66. Chader, S.; Hacene, H.; Agathos, S.N. Study of hydrogen production by three strains of Chlorella isolated from the soil in the Algerian Sahara. Int. J. Hydrog Energy 2009, 34, 4941-4946. [CrossRef] 
67. Lindblad, P.; Christensson, K.; Lindberg, P.; Fedorov, A.; Pinto, F.; Tsygankov, A. Photoproduction of H2 by wildtype Anabaena PCC 7120 and a hydrogen uptake deficient mutant: From laboratory experiments to outdoor culture. Int. J. Hydrog Energy 2002, 27, 1271-1281. [CrossRef]

68. Lin, H.D.; Liu, B.H.; Kuo, T.T.; Tsai, H.C.; Feng, T.F.; Huang, C.C.; Chien, L.F. Knockdown of PsbO leads to induction of HydA and production of photobiological H2 in the green alga Chlorella sp. DT. Bioresour. Technol. 2013, 143, 154-162. [CrossRef] [PubMed]

69. Guan, Y.; Deng, M.; Yu, X.; Zhang, W. Two-stage photo-biological production of hydrogen by marine green alga Platymonas subcordiformis. Biochem. Eng. J. 2004, 19, 69-73. [CrossRef]

70. Guo, Z.; Chen, Z.; Lu, H.; Fu, Y.; Yu, X.; Zhang, W. Sustained hydrogen photoproduction by marine green algae platymonas subcordiformis integrated with in situ hydrogen consumption by an alkaline fuel cell system. J. Biotechnol. 2008, 136, 558-576. [CrossRef]

71. Ji, C.F.; Yu, X.J.; Chen, Z.A.; Xue, S.; Legrand, J.; Zhang, W. Effects of nutrient deprivation on biochemical compositions and photo-hydrogen production of Tetraselmis subcordiformis. Int. J. Hydrog. Energy 2011, 36, 5817-5821. [CrossRef]

72. Dębowski, M.; Dudek, M.; Zieliński, M.; Nowicka, A.; Kazimierowicz, J. Microalgal Hydrogen Production in Relation to Other Biomass-Based Technologies-A Review. Energies 2021, 14, 6025. [CrossRef]

73. Oncel, S.; Vardar Sukan, F. Effect of light intensity and the light: Dark cycles on the long term hydrogen production of Chlamydomonas reinhardtii by batch cultures. Biomass Bioenergy 2011, 35, 1066-1074. [CrossRef]

74. Sun, J.; Yuan, X.; Shi, X.; Chu, C.; Guo, R.; Kong, H. Fermentation of Chlorella sp. for anaerobic bio-hydrogen production: Influences of inoculum-substrate ratio, volatile fatty acids and NADH. Bioresour. Technol. 2011, 102, 10480-10485. [CrossRef]

75. Szewczyk, K.W. Biological hydrogen production. Adv. Microbiol. 2008, 47, 241-247.

76. Kim, D.H.; Kim, M.S. Hydrogenases for biological hydrogen production. Bioresour. Technol. 2011, 102, 8423-8431. [CrossRef]

77. Das, D.; Veziroglu, T.N. Hydrogen production by biological processes: A survey of literature. Int. J. Hydrog. Energy 2001, 26, 13-28. [CrossRef]

78. Troshina, O.; Serebryakova, L.; Sheremetieva, M.; Lindblad, P. Production of H2 by the unicellular cyanobacterium Gloeocapsa alpicola CALU 743 during fermentation. Int. J. Hydrog. Energy 2002, 27, 1283-1289. [CrossRef]

79. Aoyama, K.; Lemura, I.; Miyake, J.; Asada, Y. Fermentative Metabolism to Produce Hydrogen Gas and Organic Compounds in a Cyanobacterium, Spirulina platensis. J. Ferment. Bioeng. 1997, 83, 17-20. [CrossRef]

80. Khetkorn, W.; Lindblad, P.; Incharoensakdi, A. Enhanced biohydrogen production by the N2-fixing cyanobacterium Anabaena siamensis strain TISTR 8012. Int. J. Hydrog. Energy 2010, 35, 12767-12776. [CrossRef]

81. Khetkorn, W.; Lindblad, P.; Incharoensakdi, A. Inactivation of uptake hydrogenase leads to enhanced and sustained hydrogen production with high nitrogenase activity under high light exposure in the cyanobacterium Anabaena siamensis TISTR 8012. J. Biol. Eng. 2012, 6, 19. [CrossRef] [PubMed]

82. Vergara-Fernàndez, A.; Vargas, G.; Alarcon, N.; Antonio, A. Evaluation of marine algae as a source of biogas in a two-stage anaerobic reactor system. Biomass Bioenergy 2008, 32, 338-344. [CrossRef]

83. Singh, J.; Gu, S. Commercialization potential of microalgae for biofuels production. Renew. Sustain. Energy Rev. 2010, 14, 2596-2610. [CrossRef]

84. Parmar, A.; Singh, N.K.; Pandey, A.; Gnansounou, E.; Madamwar, D. Cyanobacteria and microalgae: A positive prospect for biofuels. Bioresour. Technol. 2011, 102, 10163-10172. [CrossRef] [PubMed]

85. Dębowski, M.; Grala, A.; Zieliński, M.; Dudek, M. Efficiency of the methane fermentation process of macroalgae biomass originating from puck bay. Arch. Environ. Prot. 2012, 38, 99-107.

86. Yuan, X.Z.; Shi, X.S.; Zhang, D.L.; Qiu, Y.L.; Guo, R.B.; Wang, L.S. Biogas production and microcystin biodegradation in anaerobic digestion of blue algae. Energy Environ. Sci. 2011, 4, 1511-1515. [CrossRef]

87. Zeng, S.J.; Yuan, X.Z.; Shi, X.S.; Qiu, Y.L. Effect of inoculum/substrate ratio on methane yield and orthophosphate release from anaerobic digestion of Microcystis sp. J. Hazard. Mater. 2010, 178, 89-93. [CrossRef]

88. Chynoweth, D.P.; Turick, C.E.; Owens, J.M.; Jerger, D.E.; Peck, M.W. Biochemical methane potential of biomass and waste feedstocks. Biomass Bioenergy 1993, 5, 95-111. [CrossRef]

89. Wise, D.L.; Augenstein, D.C.; Ryther, J.H. Methane fermentation of aquatic biomass. Resour. Recovery Conserv. 1979, 4, 217-237. [CrossRef]

90. Bruhn, A.; Dahl, J.; Nielsen, H.B.; Nikolaisen, L.; Rasmussen, M.B.; Markager, S.; Olesen, B.; Arias, C.; Jensen, P.D. Bioenergy potential of Ulva lactuca: Biomass yield, methane production and combustion. Bioresour. Technol. 2011, 102, 2595-2604. [CrossRef] [PubMed]

91. Grala, A.; Zieliński, M.; Dębowski, M.; Dudek, M. Effects of hydrothermal depolymerization and enzymatic hydrolysis of algae biomass on yield of methane fermentation process. Pol. J. Environ. Stud. 2012, 2, 361-366.

92. Golueke, C.; Oswald, W.; Gotaas, H. Anaerobic digestion of algae. Appl. Environ. Microbiol. 1957, 5, 47-55. [CrossRef]

93. Zamalloa, C.; Boon, N.; Verstraete, W. Anaerobic digestibility of Scenedesmus obliquus and Phaeodactylum tricornutum under mesophilic and thermophilic conditions. Appl. Energy 2012, 92, 733-738. [CrossRef]

94. Mussgnug, J.H.; Klassen, V.; Schlüter, A.; Kruse, O. Microalgae as substrates for fermentative biogas production in a combined biorefinery concept. J. Biotechnol. 2010, 150, 51-56. [CrossRef]

95. Lee, J.W. Introduction: An Overview of Advanced Biofuels and Bioproducts. In Advanced Biofuels and Bioproducts; Lee, J., Ed.; Springer: New York, NY, USA, 2013. 
96. Miller, D.H.; Miller, M.; Lamport, D.T.A. Hydroxyproline heterooligosaccharides in Chlamydomonas. Science 1972, 176, 918-920. [CrossRef]

97. Van Eykelenburg, C.; Fuchs, A.; Schmidt, G.H. Some theoretical considerations on the in vitro shape of the cross-walls in Spirulina spp. J. Theor. Biol. 1980, 82, 271-282. [CrossRef]

98. Nakano, Y.; Urade, Y.; Urade, R.; Kitaoka, S. Isolation purification and characterization of the pellicle of Euglena gracilis. J. Biochem. 1987, 102, 1053-1063. [CrossRef] [PubMed]

99. Takeda, H. Sugar composition of the cell wall and the taxonomy of Chlorella (Chlorophyceae). J. Phycol. 1991, 27, 224-232. [CrossRef]

100. Takeda, H. Cell wall sugars of some Scenedesmus species. Phytochemistry 1996, 42, 673-675. [CrossRef]

101. Burczyk, J.; Dworzanski, J. Comparison of sporopollenin like algal resistant polymer from cell-wall of Botryococcus, Scenedesmus and Lycopodium clavatum by GC pyrolysis. Phytochemistry 1988, 27, 2151-2153. [CrossRef]

102. Hildebrand, M.; Davis, A.K.; Smith, S.R.; Traller, J.C.; Abbriano, R. The place of diatoms in the biofuels industry. Biofuels 2012, 3 , 221-240. [CrossRef] 